\title{
Twenty Landmark Papers in Biodiversity Conservation
}

\author{
Corey J. A. Bradshaw ${ }^{1,2}$, Navjot S. Sodhi ${ }^{3 \dagger}$, \\ William F. Laurance ${ }^{4,5}$ and Barry W. Brook ${ }^{1}$ \\ ${ }^{1}$ The Environment Institute and School of Earth and Environmental Sciences, \\ University of Adelaide, Adelaide, \\ ${ }^{2}$ South Australian Research and Development Institute, \\ ${ }^{3}$ Department of Biological Sciences, National University of Singapore, \\ ${ }^{4}$ School of Marine and Tropical Biology, James Cook University, Cairns, \\ ${ }^{5}$ Smithsonian Tropical Research Institute, Balboa, Ancón \\ 1,2,4 Australia \\ ${ }^{3}$ Republic of Singapore \\ 5Panama
}

\section{Introduction}

Biodiversity conservation was first defined as a science less than three decades ago (Meine, 2010), but is now a well-developed, multidisciplinary research endeavour (Sodhi \& Ehrlich, 2010). The consolidation of this 'crisis' field (Soulé, 1985) is inextricably tied to mounting global environmental degradation as the human enterprise now threatens most of the world's biodiversity and the ecosystems of which they are part (Ehrlich \& Pringle, 2008). Although the history of the field is complex and its maturation gradual (Meine, 2010; Meine et al., 2006), a modest number of key ideas have subsequently sparked enormous progress in our understanding of biodiversity's response to human impacts, and how such knowledge might help avoid extinctions.

As the planet's biotic crisis escalates, we reflect on some of the most important research discoveries in biodiversity conservation science and its progenitor disciplines. Although this is a subjective list, our rationale was to select 20 papers that either built new paradigms or tore down old ones, and set thinking along new and interesting pathways towards biodiversity conservation. Other authors would no doubt list different papers, or challenge the true origin of certain ideas we highlight. Our goal here is simply to stimulate biodiversity scientists to think about what serious innovation looks like - with the benefit of perfect hindsight - and to use this retrospective to help guide future thinking.

In the remainder of this chapter, we briefly assess these 20 papers, but make no attempt to rank their relative importance - apart from a citation analysis (Fig. 1). Although we do not consider scientific citations alone reflect a paper's value sufficiently, it does provide a simple indication of its influence on research directions. Indeed, many of the highlighted papers have proposed ideas that have subsequently been discredited or rendered obsolete. This is a natural part of the progression of science. There is nonetheless little doubt that each of these 
papers has inspired new research paths and directed conservation interventions that have arguably benefited biodiversity.

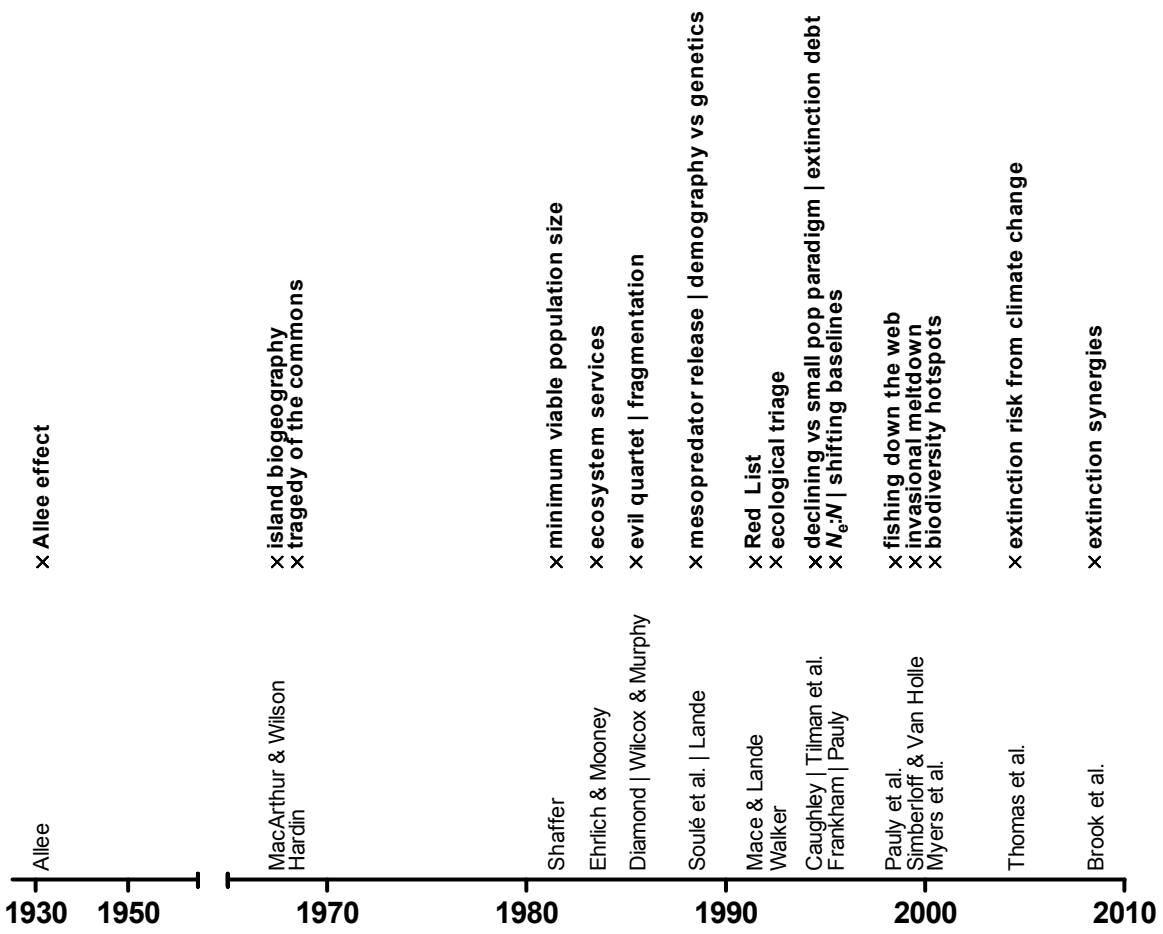

Fig. 1. Time line of the 20 landmark biodiversity conservation papers.

\section{Landmark papers}

\subsection{Allee effect (Allee, 1931)}

The 'Allee effect' can be broadly defined as a "...positive relationship between any component of individual fitness and either numbers or density of conspecifics" (Stephens et al., 1999). The idea is attributed to Warder Clyde Allee, an American ecologist from the early half of the 20th Century, although Odum (1953) first named it "Allee's principle". We consider Allee's 1931 book (Allee, 1931) to be the classic source (Fig. 2). Allee discussed the evidence for the effects of crowding on demographic and life history traits of populations, which he subsequently redefined as "inverse density dependence" (Allee, 1941).

Broadly speaking, when populations become small, a range of positive feedbacks can reduce a population's average fitness (measured in many ways, such as survival probability, reproductive rate, or growth rate). The many types of Allee effects (see Berec et al., 2007) can be mutually reinforcing (synergistic), and so drive populations even faster toward extinction than expected by their additive effects (Brook et al., 2008). Thus, ignoring potential Allee effects can compromise everything from estimates of minimum viable population size (Paper 4) to restoration attempts and predictions of extinction risk (Gregory et al., 2010). 


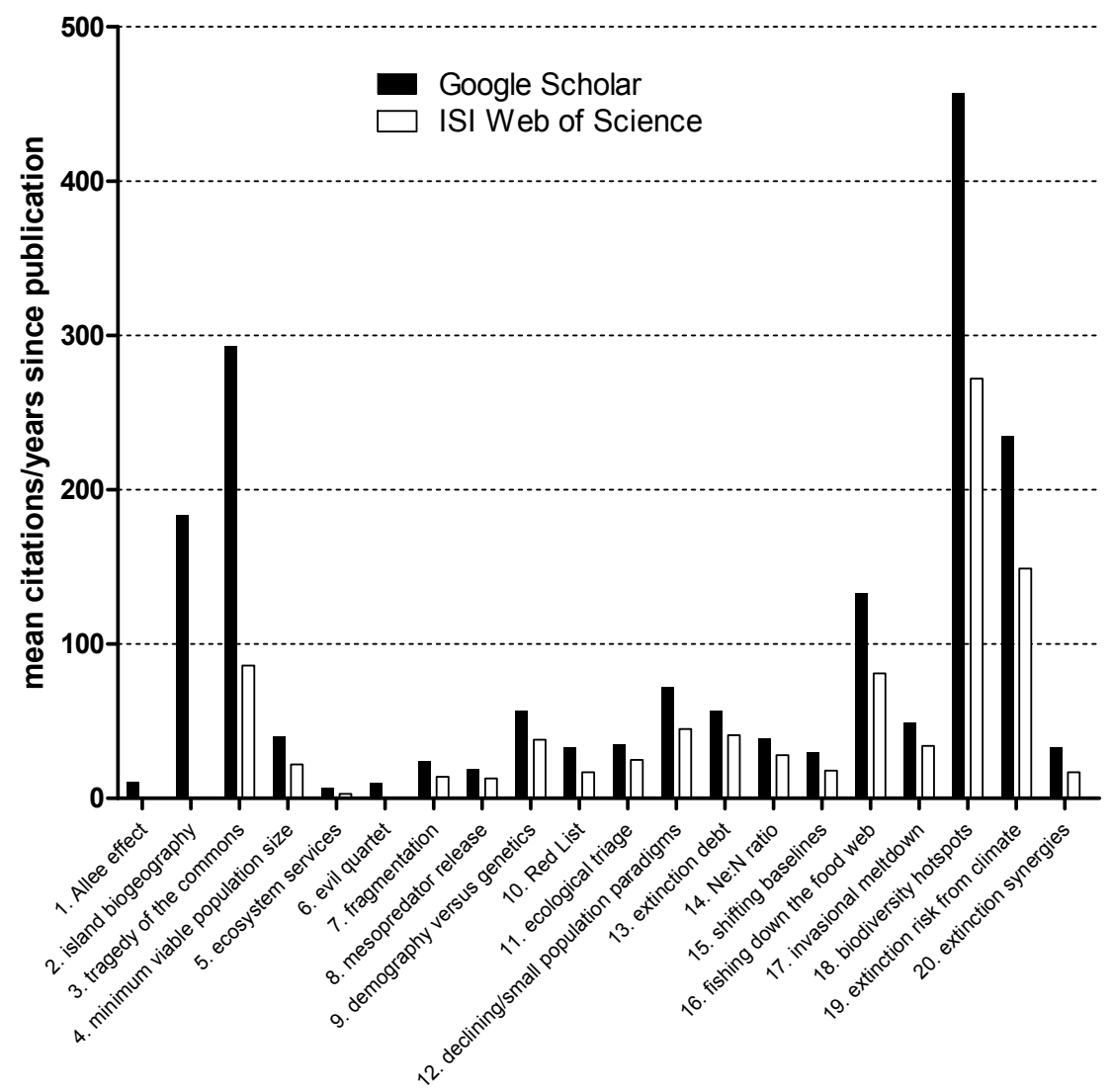

Fig. 2. Annual citation rate (total citations $\div$ years elapsed since publication) determined from Google Scholar (GS) and ISI Web of Science (ISI) for the 20 landmark papers discussed. Total citations listed as of March 2010: 1. 885 GS; 2. 7905 GS; 3. 12302 GS, 3619 ISI; 4. 1152 GS, 624 ISI; 5. 179 GS, 68 ISI; 6. 253 GS; 7. 599 GS, 340 ISI; 8. 419 GS, 291 ISI; 9. 1249 GS, 842 ISI; 10. 625 GS, 332 ISI; 11. 630 GS, 449 ISI; 12. 1147 GS, 714 ISI; 13. 913 GS, 658 ISI; 14. 587, 426 ISI; 15. 451 GS, 264 ISI; 16. 1593 GS, 969 ISI; 17. 539 GS, 372 ISI; 18. 4570 GS, 2721 ISI; 19. 1411 GS, 896 ISI; 20. 65 GS, 34 ISI.

\subsection{Island biogeography (MacArthur \& Wilson, 1967)}

This classic monograph (MacArthur \& Wilson, 1967) could be considered the principal progenitor of modern conservation science considering its influence on reserve design and the estimation of extinction rates. The original theory proposed that the number of species on islands resulted from a dynamic equilibrium between the opposing forces of colonization (a function of island isolation) and extinction (a function of island size). Put simply: the bigger the island and the closer it is to the mainland (source), the more species it should contain. This ultimately led to the branch of biogeography and conservation biology that 
applied species-area relationships (Giam et al., 2010; Guilhaumon et al., 2008; Koh \& Ghazoul, 2010; Koh et al., 2010) to habitat fragments to extrapolate total species number and-more importantly in the context of the modern extinction crisis - to estimate rates of species loss (Koh \& Ghazoul, 2010; Koh et al., 2010; Laurance, 2008). The species-area relationship literature is a hot-bed of critique and polemic (Guilhaumon et al., 2008), yet no one can deny that this seminal work spawned the idea that reduced, fragmented, and isolated areas are bad for biodiversity (e.g., Mellin et al., 2010). We would not have as many nature reserves today were it not for this simple, yet foundational, piece of science.

\subsection{Tragedy of the commons (Hardin, 1968)}

Although not a conservation biology paper per se, Hardin's classic essay (Hardin, 1968) changed the way we think about managing natural resources that lack definitive ownership. The thesis of the "tragedy of the commons" is that individuals are inherently selfish and usually place their own interests first in using commonly owned resources, thereby resulting in their depletion. Hardin used a hypothetical and simplified situation based on medieval land tenure in Europe (herders sharing a common parcel of land) on which each herder was entitled to graze his cattle. Each herder maximized his gains by putting additional cattle onto the land, even if the carrying capacity of the common was exceeded and overgrazing ensued. The herder, by making an "individually rational decision," received all the benefits from his cattle, but could in the process deplete the common resource for the entire group. If all herders make such selfish decisions then the common will be depleted, jeopardizing the livelihoods of all. Hardin's paper is now a central paradigm in natural resources management (e.g., fisheries); however, his work has been criticized most notably by Elinor Ostrom - the first woman to be awarded the Noble Prize in economics in 2009. In her classic work, Ostrom (1990) showed that when communities are given the freedom to self-govern, they are, under certain conditions, able to use the commons sustainably. Another controversial theme of Hardin's paper is that an expanding human population is a detriment to the planet and its ability to support human existence, and thus he implies that humanity needs to be educated to relinquish the freedom to breed without limit (for more recent discussion see Ehrlich \& Pringle, 2008).

\subsection{Minimum viable population size (Shaffer, 1981)}

Small populations are particularly vulnerable to extinction through random variation in birth and death rates, varying resource or habitat availability, predation, competitive interactions, single-event catastrophes and inbreeding (Gilpin \& Soulé, 1986). Enter the concept of the minimum viable population (MVP) size, which was originally defined by Shaffer (1981) as the smallest number of individuals required for an isolated population to persist (at some predefined 'high' probability) for some 'long' time into the future. In other words, the MVP size is the number of individuals needed to withstand normal (expected) variation in all the processes that affect persistence.

This simple, yet fundamental, concept provides a quantitative target for species recovery, setting reserve sizes and sustainable harvest, if calculated correctly. A danger is that it encourages 'threshold'-based decision making that is not scientifically or ethically supportable (Gilpin, 1996). MVP size served as the basis for the infamous '50/500' rule - the notion that 50 breeding individuals are needed for short-term persistence of a population, and 500 for the maintenance of long-term genetic variability - which in turn has recently 
been updated to the ' $500 / 5000$ ' rule (Traill et al., 2010a). Indeed, MVP is a concept implicitly underlying threatened species lists worldwide, including the IUCN Red List (see Paper 10). While various methodological issues, genetic considerations and policy implementation problems remain (Clements et al., 2011; Traill et al., 2010a), Shaffer's original paper (Shaffer, 1981) spawned an entire generation of research into quantitative risk assessment in conservation biology, and set the stage for deriving tangible, mathematically based conservation targets (Bradshaw \& Brook, 2010).

\subsection{Ecosystem services (Ehrlich \& Mooney, 1983)}

The concept embodied in Ehrlich and Mooney (1983) is that intact biological communities and functioning species interactions provide humanity with a host of 'services' that support or improve our quality of life. The ongoing assault on species and habitats around the globe are, in their words, "accompanied by severe degradation of the public service functions of the systems". But what are ecosystem services? The list is long, but still largely unquantified. It includes processes such as carbon storage, soil maintenance, crop pollination (Potts et al., 2010), seed dispersal, food, fuel, fibre and timber provision, water purification, flood regulation (Bradshaw et al., 2009; Bradshaw et al., 2007), disease prevention, waste decomposition and detoxification, nutrient cycling, pharmaceuticals, and cultural appreciation.

Valuing ecosystem services in any conventional sense is controversial because of the difficulty of measuring the link between ecosystem function and the services they provide, but also by the decision of whether to include direct or indirect costs of providing artificial replacement. Attempts to put them into financial terms (e.g., Costanza et al., 1997; Naidoo et al., 2008) have inevitably attracted criticism (e.g., Bockstael et al., 2000; Turner et al., 2003). Nonetheless, estimates of the gross value of ecosystem services are often remarkably high-totalling some trillions of dollars globally (European Communities, 2008) - with individual services such as insect pollination valued at more than \$US200 billion per year (Gallai et al., 2009).

\subsection{The evil quartet (Diamond, 1984)}

The 'evil quartet', or 'four horsemen of the ecological apocalypse', was probably the first treatment of extinction dynamics as a biological discipline in its own right. Diamond (Diamond, 1984) took a sweeping historical and contemporary view of extinction, then simplified the problem to four principal mechanisms: 1. overhunting (or overexploitation), 2. introduced species, 3. habitat destruction and 4. chains of linked extinctions (trophic cascades, or co-extinctions). Far from a mere review or list of unrelated mechanisms, Diamond's evil quartet crystallized conservation biologists' thinking about key mechanisms and, more importantly, directed attention towards those factors likely to drive extinctions in the future. The unique combination of prehistorical through to modern examples gave conservation biologists a holistic view of extinction dynamics and helped spawn many of the papers described hereafter.

\subsection{Habitat fragmentation (Wilcox \& Murphy, 1985)}

Despite the long-recognized notion that the more habitat you remove, the fewer species (and individuals) will persist (see Paper 2), it took decades to develop a strong consensus about the harmful consequences of fragmentation to biodiversity (Wilcox \& Murphy, 1985). Put simply, it occurs when a contiguous expanse of habitat is broken up into a number of smaller, isolated patches. The surrounding area is typically defined a less-suitable 'matrix', 
and in the case of forest fragmentation, this generally means degraded habitat, fewer native species and urban, rural or agricultural development. Fragmentation is bad for many reasons: it 1. reduces patch area, 2 . increases isolation among populations associated with fragments, 3. creates artificial 'edges' where unmodified habitat abuts matrix habitat (Saunders et al., 1991), and fundamentally alters the community and population dynamics for surviving species (Laurance, 2002). Each of these changes impacts habitat suitability, for we now know that 1 . the smaller an area, the fewer individuals and species it can contain, 2 . the more isolated a population, the less chance that immigrants will rescue it from catastrophes (Brown \& Kodric-Brown, 1977), and 3. abrupt habitat edges allow the invasion of alien species, alter microclimatic conditions, increase access to people (e.g. hunters, loggers), and can lead to cascading ecological events, such as the penetration of fire (Cochrane \& Laurance, 2002). The more fragmented an environment, the worse will be the extinction rates of species therein (Saunders et al., 1991).

\subsection{Mesopredator release (Soulé et al., 1988)}

Although popularized by Crooks and Soulé (1999), Soulé et al. (1988) first coined the term that described how ecosystems can be unbalanced by a reduction of a dominant predator that formerly exerted so-called 'top-down' control on the abundance of species at lower trophic levels. The idea had theoretical support (Litvaitis \& Villafuerte, 1996; Wright et al., 1994) but it was Soulé and colleagues (1988) who first demonstrated the phenomenon. Crooks and Soulé (1999) described an example where the decline in coyotes (Canis latrans), in combination with urbanization-driven habitat fragmentation, leads to an increase in cat (Felis catus) densities and the subsequent decline in scrub-breeding birds. More recent examples attest to the broad importance of mesopredator release: Myers et al. (2007) linked the decline of coastal shark species to mesopredator release of cownose rays (Rhinoptera bonasus), thereby driving a reduction in commercially important shellfish densities; and Johnson et al. (2006) showed how dingoes (Canis lupus dingo) in Australia suppress populations of exotic predators such as cats and foxes, leading to more locally abundant populations of native marsupials.

\subsection{Demography versus genetics (Lande, 1988)}

In an influential review, Lande (1988) argued that "demography may usually be of more immediate importance than population genetics in determining the minimum viable size of wild populations". It was a well-reasoned case, and was widely interpreted to mean that demographic and ecological threats would provide the 'killer blow' to threatened species before genetic factors such as inbreeding and fitness effects of loss of genetic diversity had time to exert a major influence on small population dynamics. Lande's paper ignited a fire under the belly of conservation geneticists, and led to a concerted effort to come up with stronger evidence for the role of genetics in elevating extinction risk. This in turn resulted in innovative field experiments (Saccheri et al., 1998), meta-analyses on genetically effective population size (Paper 14), studies on the enhanced effect of inbreeding on wild populations (Crnokrak \& Roff, 1999), and a pairwise comparison of 170 threatened taxa showing that the majority had indeed suffered from a reduction genetic diversity compared to their nonthreatened congeners (Spielman et al., 2004). The net conclusion is that demographic and genetic changes can work in concert in small populations to threaten their viability and survival (Mills \& Smouse, 1994). 


\subsection{Red List (Mace \& Lande, 1991)}

The IUCN Red List (www.iucnredlist.org) has been one of the most influential conservation policy tools constructed. For over 40000 listed species, the Red List is the main instrument used to judge their status, extinction risk, and recovery potential worldwide. The Red List is focused predominantly on vertebrates and is still far from complete (with $<2 \%$ of described species), but it is an evolving and improving expert assessment. It has become much more than a mere list - it is often used as a proxy for extinction risk (e.g., Bradshaw et al., 2008) and in cross-cutting analyses of threats to biodiversity (e.g., Laurance \& Useche, 2009). From extinction theory to conservation policy, Mace and Lande's (1991) original definition of 'red list criteria' was a major step forward for biodiversity conservation.

\subsection{Ecological triage (Walker, 1992)}

Ecological triage (Walker, 1992) is taken from the medical term triage used in emergency or wartime situations. Ecological triage refers to the conservation prioritization of species that provide unique or necessary functions to ecosystems, and little focus on those that do not have unique ecosystem roles or that face almost certain extinction given that they fall well below their MVP size (Walker, 1992). Financial resources such as investment in recovery programs, purchase of land for reserves, and habitat restoration are allocated accordingly; the species that contribute most to ecosystem function and have the highest probability of persisting are earmarked for conservation, whereas others are largely ignored (Hobbs \& Kristjanson, 2003). This pragmatic approach to conservation (labelled 'emotionally empty' or 'accounting-type' by some) is controversial because public favourites such as pandas, kakapo parrots and whales cannot be easily justified in terms of their intrinsically high costs and potentially limited benefits. According to the triage viewpoint, however, it makes no long-term conservation or economic sense to waste money on the doomed and ecologically redundant (Bottrill et al., 2008). Many in the conservation business apply ecological triage without being fully aware of it. Finite pools of money for conservation mean that we have to set priorities. Reserve design is just one example of this sacrifice-the-doomed-for-the good-of-the-ecosystem approach.

\subsection{Declining and small population paradigms (Caughley, 1994)}

Caughley's (1994) classic paper argued forcefully that two major paradigms had arisen in conservation biology, the 'declining' population paradigm and the 'small' population paradigm, yet only the former was truly scientific in allowing for the explicit testing of hypotheses. The declining population paradigm involves identifying and managing the processes that depress the demographic rates (e.g., survival and reproduction) of a species and cause its populations to decline deterministically, whereas the small population paradigm is the study of the dynamics of small populations that have declined from some (deterministic) perturbation and which are more susceptible to extinction via chance (stochastic) events. Caughley essentially argued that instead of focussing on theoretical aspects of extinction processes operating in small populations, we should instead focus our efforts on testing hypotheses exposing the drivers of population decline and arresting these. This proposition led to much debate (e.g., Hedrick et al., 1996) yet also fostered progress on more considered unification of these ideas and their applications to effective management goals such as minimum viable population size targets (Traill et al., 2010a). For instance, we now more clearly recognize that the forces that send populations into decline are not necessarily those that drive the final nail into a species' coffin. Hence, we must manage for 
both types of processes simultaneously, and the synergies between them (Brook et al., 2008; Laurance \& Useche, 2009), if we want to reduce the likelihood of species going extinct.

\subsection{Extinction debt (Tilman et al., 1994)}

This paper (Tilman et al., 1994) shattered optimistic notions that the full consequences of human activity are obvious and amenable to quick fixes. 'Extinction debt' is the concept that, as habitats become increasingly fragmented, long-lived species that are reproductively isolated from conspecifics can take generations to perish (e.g., large trees in forest fragments). This gives rise to a higher number of species than would be otherwise expected for the size of the fragment, and the false impression that many species can persist in habitat patches that are too small to sustain MVPs (Clements et al., 2011; Traill et al., 2010a). These 'living dead' or 'zombie' species are therefore committed to extinction regardless of whether habitat loss is arrested or reversed. Only assisted dispersal (Hoegh-Guldberg et al., 2008) or artificially enhanced reproduction is likely to save such species. Neglecting the extinction debt is one reason why some people have over-estimated the value of fragmented and secondary forests in guarding species against extinction (see Brook et al., 2006). It means that data on species presence collected shortly after the main habitat degradation or destruction event could give misleading signals to conservation managers about the health of ecosystems. Appreciating that the extent of expected extinctions can take generations (potentially many centuries for longlived organisms) to come to light, Tilman and colleagues' (1994) concept forced deeper thinking in the quest to minimize habitat loss and fragmentation.

\section{$2.14 N_{e}: N$ ratio (Frankham, 1995b)}

Although it had long been recognized that inbreeding and loss of genetic diversity were accentuated in small, isolated populations (Charlesworth \& Charlesworth, 1987), genetic hazards were generally considered to be of less consequence to extinction risk than demographic and environmental stochasticity (Paper 9). Frankham (1995b) helped overturn this viewpoint, using a meta-analysis to draw together comprehensive evidence on the ratio of genetically effective to actual population size $\left(N_{\mathrm{e}}: N\right)$. He assessed the effects of fluctuating population size, variance in family size and uneven sex ratios from 102 species. He found that the $N_{\mathrm{e}}: N$ ratio averaged only $10 \%$ in wild populations, signalling that even apparently large and 'secure' populations might, in reality, already be suffering from inbreeding depression and thereby require genetic management to lower their extinction risk and retain evolutionary potential.

\subsection{Shifting baselines (Pauly, 1995)}

Pauly's (1995) concept describes the way that changes to a system are measured against baselines which themselves are often degraded versions of the original state of the system. Pauly (1995) originally meant it in a fisheries context, where "... fisheries scientists sometimes fail to identify the correct 'baseline' population size (e.g., how abundant a fish species population was before human exploitation) and thus work with a shifted baseline". It is now considered a mantra in fisheries and marine science (Jackson et al., 2001), but it has been extended to many other conservation issues. Yet, quantifying shifting baselines in conservation is difficult, with little empirical evidence (but see Jackson et al., 2001), despite the logic and general acceptance of its ubiquity by conservation scientists. Papworth et al. (2009) have recently addressed this knowledge gap by defining two kinds of shifting baselines: (1) general 
amnesia ("... individuals setting their perceptions from their own experience, and failing to pass their experience on to future generations") and (2) personal amnesia (“... individuals updating their own perception of normality; so that even those who experienced different previous conditions believe that current conditions are the same as past conditions"). Humans inevitably have short memories when it comes to environmental degradation, suggesting that real-world biodiversity declines are probably far worse than many scientists realize.

\subsection{Fishing down the food web (Pauly et al., 1998)}

The trend identified by Pauly and colleagues (1998) is simple but telling: data from the United Nations' Food and Agriculture Organization revealed that the average trophic level of harvested fish has declined globally by an overall average of 0.2 units (in the sea, trophic levels range from 1 for phytoplankton to 4.6 for top predators). The trends varied by region and whether or not one takes into account certain overrepresented species, but the average decline was more or less consistent across the dataset. This work revealed that fishing on a global commercial scale has been systematically removing the largest species and then moving to smaller species as each stock is exhausted. Many species not considered palatable even a short while ago are now high-demand market items. This is one of the first high-impact papers to show that the over-fishing problem was global in extent and massive in magnitude.

\subsection{Invasional meltdown (Simberloff \& Von Holle, 1999)}

This seminal paper (Simberloff \& Von Holle, 1999) describes the mutually reinforcing ways in which non-indigenous species become invasive, transform habitats, degrade ecosystem services (Paper 5), and reduce biodiversity and thereby constitute one of the greatest threats to ecosystems today - perhaps nearly as important as habitat loss and over-exploitation (Sodhi et al., 2009). Invasional meltdown describes the process by which the negative impacts induced on native ecosystems by one invading species are exacerbated by interactions with another. Although direct information on invasion meltdowns is limited, one good example is the introduction of the yellow crazy ant (Anoplolepis gracilipes) on Christmas Island, leading to the decline of native red crabs (Gecarcoidea natalis), the dominant terrestrial herbivore. This in turn led to a proliferation of forest undergrowth from reduced crab herbivory (O'Dowd et al., 2003) and altered habitat suitability for native plant species. Invasive species interactions will be reinforced by global climate change through increasing temperatures, rising sea levels and changing rainfall patterns that increase the potential range and spread of new invading species (Brook et al., 2008), so the problem is likely to worsen.

\subsection{Biodiversity hotspots (Myers et al., 2000)}

Although published only a decade ago, Myers and colleagues' (2000) 'hotspots' concept has already become part of the classic conservation lexicon, defining areas with high species endemism and severe degradation by humans. These are places where, at current rates of habitat loss and exploitation, we stand to lose far more irreplaceable species than in similar habitats elsewhere (the concept was originally applied to terrestrial environments but later extended to the marine realm) (Roberts et al., 2002). The concept has been criticized for its inability to account for all types of threats - indeed, many other prioritization criteria have been proposed (e.g., Brooks et al., 2006; Orme et al., 2005) - but the general concept has helped to set conservation priorities for many countries. 


\subsection{Extinction risk from climate change (Thomas et al., 2004)}

Throughout the 1990s and into the new millennium, ecologists and conservation biologists accumulated many case studies quantifying the extent to which species had shifted in their geographic ranges, phenology and behaviour in response to a rapidly warming planet (Parmesan \& Yohe, 2003). However, it was not until the paper by Thomas and colleagues (2004) that the magnitude of potential species extinctions arising from climate change was projected on a global scale. While simplified and controversial (e.g., Akçakaya et al., 2006; Thuiller et al., 2004), the study has helped to catalyse the exponential rise in climate change research in conservation biology (see Parmesan, 2006; Traill et al., 2010b for recent reviews). Indeed, climate change is now seen as one of the major potential drivers of mass extinction over the next few centuries, causing Diamond's evil quartet (Paper 6) to be updated to an 'evil quintet' (Brook et al., 2008).

\subsection{Extinction synergies (Brook et al., 2008)}

We have elected to finish this list with one of our own papers (Brook et al., 2008). This was the first synthetic compilation of the evidence for extinction 'synergies' or 'multiple' stressors. Although the concept was highlighted over twenty years ago (Myers, 1987), and elaborated later in the context of deep-time extinctions (McKinney, 1997), it seems to have been largely ignored by conservation biologists until only recently (Laurance \& Useche, 2009). The concept builds on a number of ideas discussed in the other 19 papers: that separate drivers of extinction, such as habitat loss, over-exploitation, climate change, and invasive species, tend to conspire through mutually reinforcing feedbacks to heighten the extinction probability of the species they affect in a way that is greater than the sum of the individual effects. Our review compiles evidence from field studies, experiments and metaanalyses that demonstrate the amplifying actions of multiple drivers of population decline and extinction. We argued that conservation actions only targeting single drivers will usually be inadequate (and therefore potentially pointless) due to the cascading effects caused by unmanaged synergies. Time will tell if we are right.

\section{Conclusion}

Our list of 20 landmark papers in biodiversity conservation is but a tiny slice of the huge number of important research papers published in the field over the last 30 years. Although one could dispute some our specific choices, there is no doubt that the papers and ideas listed herein were highly influential and helped shape the advance of conservation biology. We excluded other papers because of the difficulty of attributing the original idea to a single source. Examples include papers discussing ecosystem stability (May, 1974), metapopulation dynamics (Hanski, 1998), inbreeding depression (Charlesworth \& Charlesworth, 1987), reserve selection (Pressey et al., 1993), estimating biodiversity (Colwell \& Coddington, 1994), the future of biodiversity (Pimm et al., 1995), and conservation genetics (Frankham, 1995a).

We speculate that, ironically, many of the authors we highlighted were probably not genuinely aware of the paradigm-shifting impact of their work at the time of publication. With this in mind, we hope that equally inspiring papers will revolutionize our thinking and actions in the coming decades. Such examinations of past leaps forward, combined with research wish lists (Sutherland et al., 2009) and future horizon-scanning exercises (e.g., Sutherland et al., 2010), will inspire the next generation of conservation-science innovators to take the field forward. 


\section{Acknowledgements}

This article was inspired by CJAB's blog http://ConservationBytes.com. Funded in part by an Australian Research Council Discovery Grant (DP0878582) to CJAB and NSS. Dedicated to the memory of Navjot S. Sodhi who died on 12 June 2011.

\section{References}

Akçakaya, H.R.; Butchart, S.H.M.; Mace, G.M.; Stuart, S.N. \& Hilton-Taylor, C. (2006). Use and misuse of the IUCN Red List Criteria in projecting climate change impacts on biodiversity. Global Change Biology, Vol.12, No.11, pp. 2037-2043, ISSN 1365-2486

Allee, W.C. (1931). Animal Aggregations: A Study in General Sociology, University of Chicago Press, ISBN 0404145019, Chicago, USA

Allee, W.C. (1941). Integration of problems concerning protozoan populations with those of general biology. American Naturalist, Vol.75, No.760, pp. 473-487, ISSN 0003-0147

Berec, L.; Angulo, E. \& Courchamp, F. (2007). Multiple Allee effects and population management. Trends in Ecology and Evolution, Vol.22, No.4, pp. 185-191, ISSN 01695347

Bockstael, N.E.; Freeman, A.M.; Kopp, R.J.; Portney, P.R. \& Smith, V.K. (2000). On measuring economic values for nature. Environmental Science and Technology, Vol.34, No.8, pp. 1384-1389, ISSN 0013-936X

Bottrill, M.C.; Joseph, L.N.; Carwardine, J.; Bode, M.; Cook, C.; Game, E.T.; Grantham, H.; Kark, S.; Linke, S.; McDonald-Madden, E.; Pressey, R.L.; Walker, S.; Wilson, K.A. \& Possingham, H.P. (2008). Is conservation triage just smart decision making? Trends in Ecology and Evolution, Vol.23, No.12, pp. 649-654, ISSN 0169-5347

Bradshaw, C.J.A. \& Brook, B.W. (2010). The conservation biologist's toolbox - principles for the design and analysis of conservation studies, In: Conservation Biology for All, N.S. Sodhi \& P.R. Ehrlich (Eds.), 313-334, Oxford University Press, ISBN 978-0199554249, Oxford

Bradshaw, C.J.A.; Brook, B.W.; Peh, K.S.-H. \& Sodhi, N.S. (2009). Flooding policy makers with evidence to save forests. Ambio, Vol.38, No.2, pp. 125-126, ISSN 0044-7447

Bradshaw, C.J.A.; Giam, X.; Tan, H.T.W.; Brook, B.W. \& Sodhi, N.S. (2008). Threat or invasive status in legumes is related to opposite extremes of the same ecological and lifehistory attributes. Journal of Ecology, Vol.96, No.5, pp. 869-883, ISSN 0022-0477

Bradshaw, C.J.A.; Sodhi, N.S.; Peh, K.S.H. \& Brook, B.W. (2007). Global evidence that deforestation amplifies flood risk and severity in the developing world. Global Change Biology, Vol.13, No.11, pp. 2379-2395, ISSN 1466-8238

Brook, B.W.; Bradshaw, C.J.A.; Koh, L.P. \& Sodhi, N.S. (2006). Momentum drives the crash: mass extinction in the tropics. Biotropica, Vol.38, No.3, pp. 302-305, ISSN 0006-3606

Brook, B.W.; Sodhi, N.S. \& Bradshaw, C.J.A. (2008). Synergies among extinction drivers under global change. Trends in Ecology and Evolution, Vol.25, No.8, pp. 453-460, ISSN 0169-5347

Brooks, T.M.; Mittermeier, R.A.; da Fonseca, G.A.B.; Gerlach, J.; Hoffmann, M.; Lamoreux, J.F.; Mittermeier, C.G.; Pilgrim, J.D. \& Rodrigues, A.S.L. (2006). Global biodiversity conservation priorities. Science, Vol.313, No.5783, pp. 58-61, ISSN 0036-8075

Brown, J.H. \& Kodric-Brown, A. (1977). Turnover rates in insular biogeography: effect of immigration on extinction. Ecology, Vol.58, No.2, pp. 445-449, ISSN 0012-9658 
Caughley, G. (1994). Directions in conservation biology. Journal of Animal Ecology, Vol.63, No.2, pp. 215-244, ISSN 0021-8790

Charlesworth, D. \& Charlesworth, B. (1987). Inbreeding depression and its evolutionary consequences. Annual Review of Ecology and Systematics, Vol.18, No.1, pp. 237-268, ISSN 0066-4162

Clements, G.R.; Bradshaw, C.J.A.; Brook, B.W. \& Laurance, W.F. (2011). The SAFE index: using a threshold population target to measure relative species threat. Frontiers in Ecology and the Environment, Vol.In press, pp., ISSN 1540-9295

Cochrane, M.A. \& Laurance, W.F. (2002). Fire as a large-scale edge effect in Amazonian forests. Journal of Tropical Ecology, Vol.18, No.3, pp. 311-325, ISSN 0266-4674

Colwell, R.K. \& Coddington, J.A. (1994). Estimating terrestrial biodiversity through extrapolation. Philosophical Transactions of the Royal Society B, Vol.345, No.1311, pp. 101-118, ISSN 0080-4622

Costanza, R.; d'Arge, R.; de Groot, R.; Farber, S.; Grasso, M.; Hannon, B.; Limburg, K.; Naeem, S.; O'Neill, R.V.; Paruelo, J.; Raksin, R.G.; Sutton, P. \& van den Belt, M. (1997). The value of the world's ecosystem services and natural capital. Nature, Vol.387, No.6630, pp. 253-260, ISSN 0028-0836

Crnokrak, P. \& Roff, D.A. (1999). Inbreeding depression in the wild. Heredity, Vol.83, No.3, pp. 260-270, ISSN 0018-067X

Crooks, K.R. \& Soulé, M.E. (1999). Mesopredator release and avifaunal extinctions in a fragmented system. Nature, Vol.400, No.6744, pp. 563-566, ISSN 0028-0836

Diamond, J.M. (1984). 'Normal' extinction of isolated populations, In: Extinctions, M.H. Nitecki (Ed.), 191-246, Chicago University Press, ISBN 0226586901, Chicago, USA

Ehrlich, P.R. \& Mooney, H.A. (1983). Extinction, substitution, and ecosystem services. BioScience, Vol.33, No.4, pp. 248-254, ISSN 0006-3568

Ehrlich, P.R. \& Pringle, R.M. (2008). Where does biodiversity go from here? A grim businessas-usual forecast and a hopeful portfolio of partial solutions. Proceedings of the National Academy of Sciences of the USA, Vol.105, No.Supplement 1, pp. 11579-11586, ISSN 0027-8424

European Communities (2008). The Economics of Biodiversity and Ecosystems. An Interim Report, European Communities, Wesseling, Germany, Available from http:/ / ec.europa.eu/environment/nature/biodiversity/economics/

Frankham, R. (1995a). Conservation genetics. Annual Review of Genetics, Vol.29, No.1, pp. 305-327, ISSN 0066-4197

Frankham, R. (1995b). Effective population size/adult population size ratios in wildlife: a review. Genetical Research, Vol.66, No.2, pp. 95-107, ISSN 0016-6723

Gallai, N.; Salles, J.-M.; Settele, J. \& Vaissière, B.E. (2009). Economic valuation of the vulnerability of world agriculture confronted with pollinator decline. Ecological Economics, Vol.68, No.3, pp. 810-821, ISSN 0921-8009

Giam, X.; Sodhi, N.S.; Brook, B.W.; Tan, H.T.W. \& Bradshaw, C.J.A. (2010). Relative need for conservation assessment of vascular plant species among ecoregions. Journal of Biogeography, Vol.38, No.1, pp. 55-68, ISSN 1365-2699

Gilpin, M. (1996). Forty-eight parrots and the origins of population viability analysis. Conservation Biology, Vol.10, No.6, pp. 1491-1493, ISSN 0888-8892 
Gilpin, M.E. \& Soulé, M.E. (1986). Minimum viable populations: processes of species extinction, In: Conservation Biology: The Science of Scarcity and Diversity, M.E. Soulé (Ed.), 19-34, Sinauer, ISBN 0878937951, Sunderland, USA

Gregory, S.; Bradshaw, C.J.A.; Brook, B.W. \& Courchamp, F. (2010). Limited evidence for the demographic Allee effect from numerous species across taxa. Ecology, Vol.91, No.7, pp. 2151-2161, ISSN 0012-9658

Guilhaumon, F.; Gimenez, O.; Gaston, K.J. \& Mouillot, D. (2008). Taxonomic and regional uncertainty in species-area relationships and the identification of richness hotspots. Proceedings of the National Academy of Sciences of the USA, Vol.105, No.40, pp. 1545815463, ISSN 0027-8424

Hanski, I. (1998). Metapopulation dynamics. Nature, Vol.396, No.6706, pp. 41-49, ISSN 00280836

Hardin, G. (1968). The tragedy of the commons. Science, Vol.162, No.3859, pp. 1243-1248, ISSN 0036-8075

Hedrick, P.W.; Lacy, R.C.; Allendorf, F.W. \& Soulé, M.E. (1996). Directions in conservation biology: comments on Caughley. Conservation Biology, Vol.10, No.5, pp. 1312-1320, ISSN 0888-8892

Hobbs, R.J. \& Kristjanson, L.J. (2003). Triage: how do we prioritize health care for landscapes? Ecological Management and Restoration, Vol.4, No.Supplement S1, pp. S39-S45, ISSN 1442-8903

Hoegh-Guldberg, O.; Hughes, L.; McIntyre, S.; Lindenmayer, D.B.; Parmesan, C.; Possingham, H.P. \& Thomas, C.D. (2008). Assisted colonization and rapid climate change. Science, Vol.321, No.5887, pp. 345-346, ISSN 0036-8075

Jackson, J.B.C.; Kirby, M.X.; Berger, W.H.; Bjorndal, K.A.; Botsford, L.W.; Bourque, B.J.; Bradbury, R.H.; Cooke, R.; Erlandson, J.; Estes, J.A.; Hughes, T.P.; Kidwell, S.; Lange, C.B.; Lenihan, H.S.; Pandolfi, J.M.; Peterson, C.H.; Steneck, R.S.; Tegner, M.J. \& Warner, R.R. (2001). Historical overfishing and the recent collapse of coastal ecosystems. Science, Vol.293, No.5530, pp. 629-638, ISSN 0036-8075

Johnson, C.N.; Isaac, J.L. \& Fisher, D.O. (2006). Rarity of a top predator triggers continentwide collapse of mammal prey: dingoes and marsupials in Australia. Proceedings of the Royal Society B: Biological Sciences, Vol.274, No.1608, pp. 341-346, ISSN 1471-2954

Koh, L.P. \& Ghazoul, J. (2010). A matrix-calibrated species-area model for predicting biodiversity losses due to land-use change. Conservation Biology, Vol.24, No.4, pp. 994-1001, ISSN 0888-8892

Koh, L.P.; Lee, T.M.; Sodhi, N.S. \& Ghazoul, J. (2010). An overhaul of the species-area approach for predicting biodiversity loss: incorporating matrix and edge effects. Journal of Applied Ecology, Vol.47, No.5, pp. 1063-1070, ISSN 1365-2664

Lande, R. (1988). Genetics and demography in biological conservation. Science, Vol.241, No.4872, pp. 1455-1460, ISSN 0036-8075

Laurance, W.F. (2002). Hyperdynamism in fragmented habitats. Journal of Vegetation Science, Vol.13, No.4, pp. 595-602, ISSN 1654-1103

Laurance, W.F. (2008). Theory meets reality: how habitat fragmentation research has transcended island biogeographic theory. Biological Conservation, Vol.141, No.7, pp. 1731-1744, ISSN 0006-3207

Laurance, W.F. \& Useche, D.C. (2009). Environmental synergisms and extinctions of tropical species. Conservation Biology, Vol.23, No.6, pp. 1427-1437, ISSN 0888-8892 
Litvaitis, J.A. \& Villafuerte, R. (1996). Intraguild predation, mesopredator release, and prey stability. Conservation Biology, Vol.10, No.2, pp. 676-677, ISSN 0888-8892

MacArthur, R.H. \& Wilson, E.O. (1967). The Theory of Island Biogeography, Princeton University Press, ISBN 0691088365, Princeton, USA

Mace, G.M. \& Lande, R. (1991). Assessing extinction threats: toward a re-evaluation of IUCN threatened species categories. Conservation Biology, Vol.5, No.2, pp. 148-157, ISSN 0888-8892

May, R.M. (1974). Stability and Complexity in Model Ecosystems, Princeton University Press, ISBN 0691088616, Princeton, USA

McKinney, M.L. (1997). Extinction vulnerability and selectivity: combining ecological and paleontological views. Annual Review of Ecology and Systematics, Vol.28, No.1, pp. 495-516, ISSN 0066-4162

Meine, C. (2010). Conservation biology: past and present, In: Conservation Biology for All, N.S. Sodhi \& P.R. Ehrlich (Eds.), 7-26, Oxford University Press, ISBN 0199554234, Oxford, United Kingdom

Meine, C.; Soulé, M. \& Noss, R.F. (2006). "A mission-driven discipline": the growth of conservation biology. Conservation Biology, Vol.20, No.3, pp. 631-651, ISSN 0888-8892

Mellin, C.; Huchery, C.; Caley, M.J.; Meekan, M.G. \& Bradshaw, C.J.A. (2010). Reef size and isolation determine the temporal stability of coral reef fish populations. Ecology, Vol.91, No.11, pp. 3138-3145, ISSN 0012-9658

Mills, L.S. \& Smouse, P.E. (1994). Demographic consequences of inbreeding in remnant populations. American Naturalist, Vol.144, No.3, pp. 412-431, ISSN 0003-0147

Myers, N. (1987). The extinction spasm impending: synergisms at work. Conservation Biology, Vol.1, No.1, pp. 14-21, ISSN 0888-8892

Myers, N.; Mittermeier, R.A.; Mittermeier, C.G.; da Fonseca, G.A.B. \& Kent, J. (2000). Biodiversity hotspots for conservation priorities. Nature, Vol.403, No.6772, pp. 853858, ISSN 0028-0836

Myers, R.A.; Baum, J.K.; Shepherd, T.D.; Powers, S.P. \& Peterson, C.H. (2007). Cascading effects of the loss of apex predatory sharks from a coastal ocean. Science, Vol.315, No.5820, pp. 1846-1850, ISSN 0036-8075

Naidoo, R.; Balmford, A.; Costanza, R.; Fisher, B.; Green, R.E.; Lehner, B.; Malcolm, T.R. \& Ricketts, T.H. (2008). Global mapping of ecosystem services and conservation priorities. Proceedings of the National Academy of Sciences of the USA, Vol.105, No.28, pp. 9495-9500, ISSN 0027-8424

O'Dowd, D.J.; Green, P.T. \& Lake, P.S. (2003). Invasional 'meltdown' on an oceanic island. Ecology Letters, Vol.6, No.9, pp. 812-817, ISSN 1461-0248

Odum, E. (1953). Fundamentals of Ecology, WB Saunders Co., ISBN 0534420664, Philadelphia, USA

Orme, C.D.L.; Davies, R.G.; Burgess, M.; Eigenbrod, F.; Pickup, N.; Olson, V.A.; Webster, A.J.; Ding, T.-S.; Rasmussen, P.C.; Ridgely, R.S.; Stattersfield, A.J.; Bennett, P.M.; Blackburn, T.M.; Gaston, K.J. \& Owens, I.P.F. (2005). Global hotspots of species richness are not congruent with endemism or threat. Nature, Vol.436, No.7053, pp. 1016-1019, ISSN 0028-0836

Ostrom, E. (1990). Governing the Commons: The Evolution of Institutions for Collective Action, Cambridge University Press, ISBN 0521405998, Cambridge, United Kingdom 
Papworth, S.K.; Rist, J.; Coad, L. \& Milner-Gulland, E.J. (2009). Evidence for shifting baseline syndrome in conservation. Conservation Letters, Vol.2, No.2, pp. 93-100, ISSN 1755$263 X$

Parmesan, C. (2006). Ecological and evolutionary responses to recent climate change. Annual Reviews in Ecology, Evolution and Systematics, Vol.37, No.1, pp. 637-669, ISSN 0066-4162

Parmesan, C. \& Yohe, G. (2003). A globally coherent fingerprint of climate change impacts across natural systems. Nature, Vol.421, No.6918, pp. 37-42, ISSN 0028-0836

Pauly, D. (1995). Anecdotes and the shifting baseline syndrome of fisheries. Trends in Ecology and Evolution, Vol.10, No.10, pp. 430, ISSN 0169-5347

Pauly, D.; Christensen, V.; Dalsgaard, J.; Froese, R. \& Torres Jr., F. (1998). Fishing down marine food webs. Science, Vol.279, No.5352, pp. 860-863, ISSN 0036-8075

Pimm, S.L.; Russell, G.J.; Gittleman, J.L. \& Brooks, T.M. (1995). The future of biodiversity. Science, Vol.269, No.5222, pp. 347-350, ISSN 0036-8075

Potts, S.G.; Biesmeijer, J.C.; Kremen, C.; Neumann, P.; Schweiger, O. \& Kunin, W.E. (2010). Global pollinator declines: trends, impacts and drivers. Trends in Ecology and Evolution, Vol.25, No.6, pp. 345-353, ISSN 0169-5347

Pressey, R.L.; Humphries, C.J.; Margules, C.R.; Vane-Wright, R.I. \& Williams, P.H. (1993). Beyond opportunism: key principles for systematic reserve selection. Trends in Ecology and Evolution, Vol.8, No.4, pp. 124-128, ISSN 0169-5347

Roberts, C.M.; McClean, C.J.; Veron, J.E.N.; Hawkins, J.P.; Allen, G.R.; McAllister, D.E.; Mittermeier, C.G.; Schueler, F.W.; Spalding, M.; Wells, F.; Vynne, C. \& Werner, T.B. (2002). Marine biodiversity hotspots and conservation priorities for tropical reefs. Science, Vol.295, No.5558, pp. 1280-1284, ISSN 0036-8075

Saccheri, I.; Kuussaari, M.; Kankare, M.; Vikman, P.; Fortelius, W. \& Hanski, I. (1998). Inbreeding and extinction in a butterfly metapopulation. Nature, Vol.392, No.6675, pp. 491-494, ISSN 0028-0836

Saunders, D.A.; Hobbs, R.J. \& Margules, C.R. (1991). Biological consequences of ecosystem fragmentation: a review. Conservation Biology, Vol.5, No.1, pp. 18-32, ISSN 0888-8892

Shaffer, M.L. (1981). Minimum population sizes for species conservation. BioScience, Vol.31, No.2, pp. 131-134, ISSN 0006-3568

Simberloff, D. \& Von Holle, B. (1999). Positive interactions of nonindigenous species: invasional meltdown? Biological Invasions, Vol.1, No.1, pp. 21-32, ISSN 1387-3547

Sodhi, N.S.; Brook, B.W. \& Bradshaw, C.J.A. (2009). Causes and consequences of species extinctions, In: The Princeton Guide to Ecology, S.A. Levin (Ed.), 514-520, Princeton University Press, ISBN 978-0-691-12839-9, Princeton, USA

Sodhi, N.S. \& Ehrlich, P.R. (2010). Conservation Biology for All, Oxford University Press, ISBN 0199554234, Oxford, United Kingdom

Soulé, M. (1985). What is conservation biology? BioScience, Vol.35, No.11, pp. 727-734, ISSN 0006-3568

Soulé, M.E.; Bolger, D.T.; Alberts, A.C.; Sauvajot, R.S.; Wright, J.; Sorice, M. \& Hill, S. (1988). Reconstructed dynamics of rapid extinctions of chaparral-requiring birds in urban habitat islands. Conservation Biology, Vol.2, No.1, pp. 75-92, ISSN 0888-8892

Spielman, D.; Brook, B.W. \& Frankham, R. (2004). Most species are not driven to extinction before genetic factors impact them. Proceedings of the National Academy of Sciences of the USA, Vol.101, No.42, pp. 15261-15264, ISSN 0027-8424 
Stephens, D.W.; Sutherland, W.J. \& Freckleton, R.P. (1999). What is the Allee effect? Oikos, Vol.87, No.1, pp. 185-190, ISSN 0030-1299

Sutherland, W.J.; Adams, W.M.; Aronson, R.B.; Aveling, R.; Blackburn, T.M.; Broad, S.; Ceballos, G.; Côté, I.M.; Cowling, R.M.; Da Fonseca, G.A.B.; Dinerstein, E.; Ferraro, P.J.; Fleishman, E.; Gascon, C.; Hunter Jr., M.; Hutton, J.; Kareiva, P.; Kuria, A.; Macdonald, D.W.; Mackinnon, K.; Madgwick, F.J.; Mascia, M.B.; Mcneely, J.; Milner-Gulland, E.J.; Moon, S.; Morley, C.G.; Nelson, S.; Osborn, D.; Pai, M.; Parsons, E.C.M.; Peck, L.S.; Possingham, H.; Prior, S.V.; Pullin, A.S.; Rands, M.R.W.; Ranganathan, J.; Redford, K.H.; Rodriguez, J.P.; Seymour, F.; Sobel, J.; Sodhi, N.S.; Stott, A.; Vance-Borland, K. \& Watkinson, A.R. (2009). One hundred questions of importance to the conservation of global biological diversity. Conservation Biology, Vol.23, No.3, pp. 557-567, ISSN 1523-1739

Sutherland, W.J.; Clout, M.; Côté, I.M.; Daszak, P.; Depledge, M.H.; Fellman, L.; Fleishman, E.; Garthwaite, R.; Gibbons, D.W.; De Lurio, J.; Impey, A.J.; Lickorish, F.; Lindenmayer, D.; Madgwick, J.; Margerison, C.; Maynard, T.; Peck, L.S.; Pretty, J.; Prior, S.; Redford, K.H.; Scharlemann, J.P.W.; Spalding, M. \& Watkinson, A.R. (2010). A horizon scan of global conservation issues for 2010. Trends in Ecology and Evolution, Vol.25, No.1, pp. 1-7, ISSN 0169-5347

Thomas, C.D.; Cameron, A.; Green, R.E.; Bakkenes, M.; Beaumont, L.J.; Collingham, Y.C.; Erasmus, B.F.N.; de Siqueira, M.F.; Grainger, A.; Hannah, L.; Hughes, L.; Huntley, B.; van Jaarsveld, A.S.; Midgley, G.F.; Miles, L.; Ortega-Huerta, M.A.; Peterson, A.T.; Phillips, O.L. \& Williams, S.E. (2004). Extinction risk from climate change. Nature, Vol.427, No.6970, pp. 145-148, ISSN 0028-0836

Thuiller, W.; Araújo, M.B.; Pearson, R.G.; Whittaker, R.J.; Brotons, L. \& Lavorel, S. (2004). Biodiversity conservation: uncertainty in predictions of extinction risk. Nature, Vol.430, No.6995, pp. doi:10.1038/nature02716, ISSN 0028-0836

Tilman, D.; May, R.M.; Lehman, C.L. \& Nowak, M.A. (1994). Habitat destruction and the extinction debt. Nature, Vol.371, No.6492, pp. 65-66, ISSN 0028-0836

Traill, L.W.; Brook, B.W.; Frankham, R. \& Bradshaw, C.J.A. (2010a). Pragmatic population viability targets in a rapidly changing world. Biological Conservation, Vol.143, pp. 2834, ISSN 0006-3207

Traill, L.W.; Lim, M.L.M.; Sodhi, N.S. \& Bradshaw., C.J.A. (2010b). Mechanisms driving change: altered species interactions and ecosystem functions from global warming. Journal of Animal Ecology, Vol.79, No.5, pp. 937-947, ISSN 0021-8790

Turner, R.K.; Paavola, J.; Cooper, P.; Farber, S.; Jessamy, V. \& Georgiou, S. (2003). Valuing nature: lessons learned and future research directions. Ecological Economics, Vol.46, No.3, pp. 493-510, ISSN 0921-8009

Walker, B.H. (1992). Biodiversity and ecological redundancy. Conservation Biology, Vol.6, No.1, pp. 18-23, ISSN 0888-8892

Wilcox, B.A. \& Murphy, D.D. (1985). Conservation strategy: the effects of fragmentation on extinction. American Naturalist, Vol.125, No.6, pp. 879-887, ISSN 0003-0147

Wright, S.J.; Gompper, M.E. \& DeLeon, B. (1994). Are large predators keystone species in Neotropical forests? The evidence from Barro Colorado Island. Oikos, Vol.71, No.2, pp. 279-294, ISSN 0030-1299 


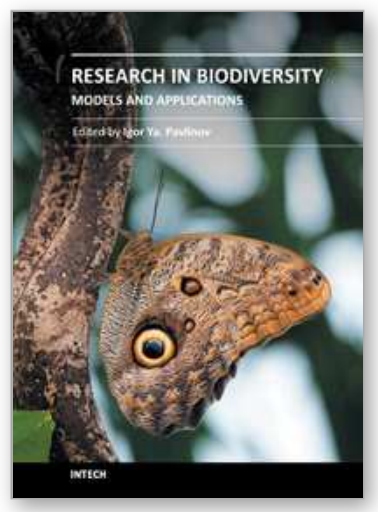

\author{
Research in Biodiversity - Models and Applications \\ Edited by Dr. Igor Pavlinov
}

ISBN 978-953-307-794-9

Hard cover, 364 pages

Publisher InTech

Published online 12, October, 2011

Published in print edition October, 2011

The book covers several topics of biodiversity researches and uses, containing 17 chapters grouped into 5 sections. It begins with an interesting chapter considering the ways in which the very biodiversity could be thought about. Noteworthy is the chapter expounding pretty original "creativity theory of ecosystem". There are several chapters concerning models describing relation between ecological niches and diversity maintenance, the factors underlying avian species imperilment, and diversity turnover rate of a local beetle group. Of special importance is the chapter outlining a theoretical model for morphological disparity in its most widened treatment. Several chapters consider regional aspects of biodiversity in Europe, Asia, Central and South America, among them an approach for monitoring conservation of the regional tropical phytodiversity in India is of special importance. Of interest is also a chapter considering the history of the very idea of biodiversity emergence in ecological researches.

\title{
How to reference
}

In order to correctly reference this scholarly work, feel free to copy and paste the following:

Corey J. A. Bradshaw, Navjot S. Sodhi, William F. Laurance and Barry W. Brook (2011). Twenty Landmark Papers in Biodiversity Conservation, Research in Biodiversity - Models and Applications, Dr. Igor Pavlinov (Ed.), ISBN: 978-953-307-794-9, InTech, Available from: http://www.intechopen.com/books/research-inbiodiversity-models-and-applications/twenty-landmark-papers-in-biodiversity-conservation

\section{INTECH}

open science | open minds

\author{
InTech Europe \\ University Campus STeP Ri \\ Slavka Krautzeka 83/A \\ 51000 Rijeka, Croatia \\ Phone: +385 (51) 770447 \\ Fax: +385 (51) 686166 \\ www.intechopen.com
}

\author{
InTech China \\ Unit 405, Office Block, Hotel Equatorial Shanghai \\ No.65, Yan An Road (West), Shanghai, 200040, China \\ 中国上海市延安西路65号上海国际贵都大饭店办公楼 405 单元 \\ Phone: +86-21-62489820 \\ Fax: $+86-21-62489821$
}


(C) 2011 The Author(s). Licensee IntechOpen. This is an open access article distributed under the terms of the Creative Commons Attribution 3.0 License, which permits unrestricted use, distribution, and reproduction in any medium, provided the original work is properly cited. 